\title{
Audiovisual Translation in the Light of the Main Dialectic Principles
}

\author{
Vera E. Gorshkova* \\ Eurasian Linguistic Institute \\ 8 Lenin Str., Irkutsk, 664025, Russia
}

Received 10.02.2016, received in revised form 17.02.2016, accepted 04.02.2016

The article proves a possibility to use the dialectic method as the means and the way to theoretically comprehend some facts of reality in regard to audiovisual translation. The main dialectic laws such as principles of the unity and conflict of opposites, the quantity into quality transformation and the negation of the negation are illustrated by examples of audiovisual translation terms evolution, translation of substandard lexical units, approaches to rendering foreign accents of film characters.

Keywords: audiovisual translation (AVT), subtitling, dubbing, dialectic, the principle of the unity and conflict of opposites, the principle of the quantity into quality transformation, the principle of the negation of the negation.

DOI: 10.17516/1997-1370-2016-9-3-528-535.

Research area: philology.

Philosophy as a creative act has nothing in common with either naturalistic or mathematical cognition - it is an art.

Nycolas Berdyaev

That ordinary dialectic is of no use to those who wish to investigate the truth of things. Its sole advantage is that it sometimes enables us to explain to others arguments which are already known. It should therefore be transferred from philosophy to rhetoric.

Rene Decartes

The idea of developing a systemological model of translation studies suggested by N.K. Garbovsky and implemented in the reasoning of the systemic transdisciplinarity paradigm (Garbovsky, 2015, p. 4-16) allows to regard many issues of translation studies from a new view point applying data of a number of sciences that are sometimes quite distinct from its linguistic component proper. We have already taken an attempt to analyze audiovisual translation (AVT) applying the notions of the French researcher J.-F. Cornu (Gorshkova,

(C) Siberian Federal University. All rights reserved

* Corresponding author E-mail address: Gorchkova_v@mail.ru 
2015, p. 22-37; Cornu, 2014). The study we have undertaken to establish the position of the AVT in the systemic transdisciplinarity paradigm proves that it is possible to include such a pivotal science as philosophy into the above mentioned paradigm. Considering an argosy of notions and categories treated by this universal discipline, let us study AVT from the view point of three dialectic principles that every educated person remembers well from the university studies time.

\section{The unity and conflict of opposites in audiovisual translation}

Encyclopedic Dictionary of Philosophy says «a characteristic feature of any object determinable under the principle of the unity and conflict of opposites points at the source of its motion and development that lies in the given object rather than outside or in some supernatural forces. The principle provides an insight into comprehending any integral entity as a complex and dismembered system, incorporating elements and trends that aren't directly consistent. The principle of the unity and conflict of opposites disclaims the final nature of a finite form of existence in the natural environment or society, putting us on the path of understanding fragility of such forms and their evolution into higher and more developed ones as soon as they reach the end of their resources» (FES, 1983, p. 183-184) (italics is ours - V.G.).

As we can see the principle of the unity and conflict of opposites is based first and for most on such fundamental notions as integrity and system that are inseparably bounded; furthermore, they are mutually intersecting concepts which implies a possibility to use them virtually as synonyms. In regard to translation we suppose that audiovisual translation requires a systemic approach to its implementation, careful consideration of components of the film that is perceived and experienced by the audience. As to integrity, it is understood in philosophy as «a web of various objective and structural features allowing one to arrive at conclusions about an integral entity even if empirical evidence is scarce and thus sense is built-up on the basis of the existing knowledge and experience» (SFS, 2004, p. 467), and hence it maintains creation (build-up) of the sense-image that, being, in our opinion, the fundamental concept of AVT, is to be adequately rendered in the translation of a film dialogue (Gorshkova, 2010, 2014, 2015; Kolodina, 2013, 2014).

The idea that system elements and trends «that are not directly consistent» appearing in the above definition seems to be the most relevant aspect of the principle of the unity and conflict of opposites representation. What way can that aspect be considered in regard to AVT?

Our considerations are grounded on the fact that, speaking about feature films, AVT falls into a specific type of literary translation taking into account that it is implemented within the context of art, to be more exact, of the art of cinematography with its own laws that are determined by the particular character of the medium (Gorshkova, 2006/2008). There is an opinion that «no omissions, additions or changes are allowed in literary translation. If a translated fiction text has any drawbacks, these drawbacks are to be rendered faithfully. Such translation is aimed at substituting the original for those who can't read it because they don't know the language and providing them with the means and an opportunity to revel in the text and estimate it» (Nelyubin, 2003, p. 246).

Our research shows that representation of the given dialectic principle depends on the AVT type / technique. Thus, subtitling has very strict time and space limits, the latter postulates the limited number of signs in an intended subtitle which, on the one hand, highlights the fact that philosophical categories of space and time are inextricably intertwined. On the other hand, such 
a technique is bound to contradict a postulated literary translation requirement to avoid «additions» or «changes»: the former are hardly possible due to an obvious necessity to limit considerably the verbal component in the written form, while the latter can hardly be avoided when translating film dialogues dominated by the WORD. The above contradictions can be managed and «the conflict of opposites» can be settled resulting in «the unity» only thanks to a translator's endeavor to render the sense-image of a film dialogue adequately, on the basis of the «subject», i.e. the film itself as a semiotically complex whole that is a «source» of inspiration for the translator.

A language polyphony in a film also comes into a contradiction with the whole in the case of subtitling; however this conflict is completely settled when the AVT type / technique of dubbing is used. For example, when a translator creates subtitles he/she has to focus on the foremost cues that optimally represent the sense-image of the film dialogue loosing less relevant verbal «background noise» present in the original (restaurant, street, concert hall rhubarb).

The challenge of substandard vocabulary translation holds a specific place in the context of our study (Gorshkova, 2006/2008, 2014). It is a common knowledge that a spoken word is less shocking than a written one. Thus, as the audience can build-up the extent of substandard in the register «on the basis of the existing knowledge and experience» (see above), a translator moderates the invective vocabulary for ethical reasons, as soon as it can produce a mixed response of the audience which again conflicts literary translation in its classical interpretation. So, some translators prefer to rely on their own strategies aimed at the best result in order to keep authentic features of substandard lexical units while rendering them in such a way that they won't shock the audience. For example,
Isabelle Audinot, a translator from Switzerland, describes her «throes of translation» while subtitling the film «Project $X »$ by the British director Nima Nourizadeh (UK, 2012). The film is rich in colloquialisms, youth-speak, to be more exact. At first, the translator tired to be faithful to the English original. However when the film was viewed with preliminary subtitles in French it turned out that her translation couldn't be used: the text was so substandard that it came into a conflict with the video image and prevented the audience from perceiving the film as the whole. Vulgar and coarse expressions, verlan ${ }^{1}$, that came across as relatively unceremonious in a spoken everyday discourse appeared absolutely inadequate in subtitles as these lexical units are hardly ever used in the written speech. Taking these facts into consideration, Ms. Audinot moderated the substandard character of the above mentioned lexical units, so that their number was reduced and only some «signal» elements were kept, which resulted in a qualitative improvement of the audience's response to the film (see below, the quantity into quality principle). Moreover, she tested changes of the subtitles with teenagers who subjected them to fierce and forthright criticism: «J'ai également testé mes sous-titres sur des jeunes qui ont été sans pitié... Ce qui est très bien» (Boillat, Cordonnier, 2013, p. 16-17).

Now, let us examine the second part of the principle under analysis. It is clear that audiovisual translation as well as translation activity as a whole «disclaims the final nature of a finite form of existence». Thereupon, it is interesting to compare periods of time it takes the French and the Swiss to read subtitles: this parameter is much higher for the former than the latter. It can be accounted for by the fact that in France (and the EU in general) subtitles are traditionally displayed on the screen in two lines, 32-41 signs in each one (Diaz Cintas, 2008), 
while in Switzerland several languages subtitles are displayed at the same time which results in the requirement to represent them in a very laconic way, a single line for each language. As researchers say, the trend becomes irrelevant due to the rise of information processing technologies because DSP (Digital Signal Processing) makes it possible to enter a special code and get an access to subtitles in the given official language that prevails in a particular canton due to a particular nature of the Swiss state structure but regardless the actual language of the audience (Boillat, Cordonnier, 2013).

Thus, our observations prove the principle of the unity and conflict of opposites is generally aimed at «the evolution [of forms of existence] into higher and more developed ones as soon as they reach the end of their resources».

\section{The principle of the quantity into quality transformation}

It is to be recalled that according to the principle of the quantity into quality transformation «changes in the subject quality take place when quantitative changes are accumulated to a particular limit. $<\ldots>$ Every qualitative change comes as a change in elements of the system. The extent of discrepancy between the old and the new quality depends on qualitative changes in the subject under examination» (FES, 1983, p. 488).

The way the above principle is implemented can be illustrated by an example of the audiovisual terminology development. Thus, for a long time there were strong doubts whether subtitling could be regarded as translation proper. When dealing with the given AVT type / technique, scholars preferred to use the term «adaptation», which was interpreted in a generalized form as $«<\ldots>$ various types of text processing: simplification of its contents and form, preservation of the text with the purpose of customizing it to readers who are not ready to perceive the text in its original form» (Nelyubin, 2003, p. 13). That is probably the reason why scientists excluded that fascinating field of research from their studies and mainly relied on the classical definitions of translation that had been given long before cinema, television and digital technologies came into being.

We faced the same problem in the research of film dialogue which gave us grounds to title our first monograph in a rather general way «Film Translation» (Gorshkova, 2006/2008). Search of a Russian equivalent for the term «subtitling» turned out particularly challenging as it was not given in any Soviet or Russian dictionary of cinematographic terms known to us. The equivalent suggested by us, «перевод $\boldsymbol{c}$ субтитрами» (lit. «translation with subtitles»), stirred up many disputes which resulted in our decision to omit the preposition «c» (with) in it «перевод субтитрами» (subtitling). In a series of recent articles we have come across such terms as «субтитрирование» (subtitulation) and even «субтитровый перевод» (lit. «translation by subtitles») (Chanysheva, 2015). Moreover, some scholars believe that AVT should be grounded on the concept of «accessibility» (accessibilité) for the audience: «In the society enunciating principles of equality and integration, the notion of accessibility bears a social connotation and requires to open access to audiovisual programs for those who cannot get access to them for a specific reason» (Diaz Cintas, 2008, p. 29). (Compare it with the above definition of adaptation given in «Explanatory Dictionary of Translation Studies» by L.L. Nelyubin).

The dispersed character of AVT terminology (quantity) sets up a requirement to generalize it in order to prevent a possibility of misunderstanding between researchers and practicing translators (quality). It is no coincidence that the on-line magazine «L'Ecran traduit», established in 2013 by the Association of Audiovisual Translators/ 
Adaptors, France, $\left(\mathrm{ATAA}^{2}\right)$, published a glossary aimed at elaborating and unifying data that are scattered in different works concerning the AVT terminology (Glossaire, 2014, p. 2). Speaking about subtitles, even though there are well established terms «subtitling» and «sous-titrage» in English and French respectively, there also exists a great variety of translation techniques aimed at particular audience categories (including closed captioning or subtitling for the deaf and hard-of-hearing and audio description for the blind and visually impaired), which suggests that existing general term «audiovisual translation» can be reasonably considered an example of transfer «from the old to the new, from one measure to another one» (FES, 1983, p. 488).

\section{The principle of the negation}

\section{of the negation vs audiovisual translation}

As far as the principle of the negation of the negation is concerned it describes «the line of the development process, the unity of incremental changes and continuity in the development, emergence of the new and relative repetitiveness of old elements. $<_{\ldots}>>$ While the principle of the unity and the conflict of opposites determines a source of development, the quantity into quality principle sets a development mechanism, the principle of the negation of the negation states development in its trend, form and result. The negation of negation effect can be observed in full only in the integral, relatively complete development process, in a sequence of interrelated changes when it is possible to establish a more or less complete (from the development point of view) result. At a separate stage the given principle can be observed only as a trend» (FES, 1983, p. 471).

The way the above mentioned principle is implemented in AVT can be illustrated by a challenge of translation of a character's foreign accent present in the original film. Let us recall words of John Truby, a renowned American scholar, who addressed scriptwriting beginners in his Bible of screenwriting saying that when writing a script one «should follow a unique manner of speaking of each character» (Truby, 2010 , p. 257). The same idea is suggested by Sergey Kozin, a brilliant Russian translator and an expert in audiovisual translation, who believes that adequate rendering of the character's manner of speaking, staying in sync with its characteristic features in accordance with the genre and style is one of the main rules of spoken word translation (in films). He writes: "If a character's speech differs from the others' speech, one should be able to notice it and render adequately otherwise the character will be depersonalized and killed. Dubbing kills the part: the actor loses one the crucial tools - his/her voice. To keep the part alive it should be created anew; so you need another good actor and a good text. Good dubbing is probably a case when you listen to the film and forget that it is dubbed because it sounds so natural and smooth» (Kozin).

Let us analyze two very far and very close languages (as Bernard Shaw once put it) - the British and the American English in the light of the above cited. As audiovisual translators note, even if peculiarities of these languages are properly reflected in Hollywood films, they are far from obvious when such film is screened for the French audience. Consider an example: when the film «Inglourious Basterds ${ }^{3}$ » by Quentin Tarantino (USA/ Germany, 2009) was dubbed into French, the difference in the verbal expression of the American lieutenant Aldo Raine (Bred Pitt) and Archi Hicox from Britain (Michael Fassbender) was successfully compensated by lexical means used in the French translation of the film. Thus, the American who is characterized by vulgarity of verbal expression, constantly uses colloquialisms and even dirty words. As for the British, he uses lexical units of 
the lofty language; moreover, a refined syntax is typical of him which is reflected, among others, in applying inversion of the subject and predicate in interrogative sentences. Carefully following the above strategy of the film dialogue translation one has an opportunity to get, in terms of the negation of negation principle, «a more or less complete (from the development point of view) result», i.e. to demonstrate an evident difference in the manner of speaking of the characters that shows where they come from.

Hence, the above analysis indicates that introducing philosophy into the paradigm of systemic transdisciplinarity with the purpose of audiovisual translation research and applying dialectic as the means and the way to theoretically comprehend phenomena related to this particular translation type can be very efficient.

\footnotetext{
Verlan - an argot in the French language, featuring inversion of syllables in a word. For example, laisse tomber - laisse béton.

2 ATAA - Association des traducteurs/adaptateurs de l'audiovisuel (ataa.fr/revue/).

3 The title is deliberately given in the above form. When asked to explain his reasons of making two spelling mistakes in the film title, Quentin Trantino replied: «I can’t tell you». However, journalists drew his confession: «And the "basterds" part? That's just the way you say it: basterds». This fact allowed Anrey Plakhov, a Russian film expert and critic, to suggest his translation of the title - «Безславные ублютки» (Wikipedia).
}

\section{References}

Boillat, A., Cordonnier, L. (2013). La traduction audiovisuelle: contraintes (et) pratiques. Entretien avec Isabelle Audinot et Sylvestre Meininger. In Décadrages. Cinéma à travers champs. Lausanne : Université de Lausanne, 23-24, 9-27.

Cornu, J.-F. (2014). Le doublage et le sous-titrage. Histoire et esthétique. Rennes: Presses universitaires de Rennes, $440 \mathrm{p}$.

Chanysheva, Z.Z. (2015). Problema trasliruemosti xenonimov (na materiale subtitrovih perevodov amerikanskih filmov) [The issue of xenonyms translatability (on the material of subtitles of American films)]. Professional'no-orientirovannij perevod: real'nost' i perspectivi: sb. nauch. trudov 10i Mezhd. nauch.-metod. internet koferentsii [Professionally oriented translation: reality and prospects. Proceedings of the 10th Int. scient. and method. Internet conference]. Moscow, 181-197.

Diaz Cintas, J. (2008). Pour une classification des sous-titres à l'époque du numérique, In La traduction audiovisuelle. Approche interdisciplinaire du sous-titrage/ Eds. Jean Lavaur et Adriana Şerban. Bruxelles: De Boeck, 27-41.

FES (1983). Filosofskij entsiklopedicheskij slovar' [Encyclopedic Dictionary of Philosophy]. Moscow, Sovetskaja entsiclopedia, $840 \mathrm{p}$.

Garbovsky, N.K. (2015). Sistemologicheskaja model' nauki o perevode. Transdisciplinarnost' $i$ sistema nauchnih znanij [Systemological model of translatology: transdisciplinarity and the system of scientific knowledge], In Vestnik Moskovskogo Universiteta. Seria 22. Teorija perevoda [Moscow State University Bulletin. Series 22: Theory of Translation], 1, 7-20.

Gorshkova, V.E. (2015). Estetika audiovizual'nogo perevoda J.-F. Kornu v paradgme sistemnoj transdisciplinarnosti [Aesthetics of audiovisual translation by Jean-François Cornu within the paradigm of systemic transdisciplinarity], In Vestnik Moskovskogo Universiteta. Seria 22. Teorija perevoda [Moscow State University Bulletin. Series 22: Theory of Translation], 3, 22-37.

Gorshkova, V.E. et al. (2014). Kinodialog. Obraz-smisl. Perevod [Film-dialogue. Image-sense. Translation]: kollektivnaja monografija / Pod obsch. red. prof. V.E. Gorshkovoj. Irkutsk, MGLU EALI, 367 p., available at: http://rucont.ru/efd/326468 
Gorshkova, V.E. (2010). Perevod kinodialoga v svete konceptcii Zhilja Deljoza [Film dialogue translation in the light of Gilles Deleuze's conception], In Vestnik Moskovskogo Universiteta. Seria 22. Teorija perevoda [Moscow State University Bulletin. Series 22: Theory of Translation], 1, 16-26.

Gorshkova, V.E. (2006/2008). Perevod v kino: monographia [Film Translation: monograph]. Irkutsk: Irkutsk State Linguistic University, 267 p., available at: http://rucont.ru/efd/199913

Gorshkova, V.E. (2006). Perevod snizhennoj lexiki $v$ sovremennom frantsuzskom kino [Substandard vocabulary translation in contemporary French films], In Vestnik Moskovskogo Universiteta. Seria 19. Lingvistika i mezhkul'turnaja kommunikatsija [Moscow State University Bulletin. Series 19: Linguistic and Intercultural Communication], 1, 81-96.

Kozin, S. Glavnaia zapoved' perevodchika - ne navredi [The most basic commandment of a translator is do no harm], available at: http://vozduh.afisha.ru/archive/translators-on-translation/

Glossaire (2014). Glossaire de la traduction audiovisuelle et professionnelle / mot d'introduction S. Gourgeon, In L'Ecran traduit. Hors série, 2, 50 p. available at: http://ataa.fr/revue

Kolodina, E.A. (2014). Obraz-smisl kak generator i aktualizator smisla v prostranstve kinodiskursa. Glava 7 [Image-sense as an agent of sense generation and actualization in the sphere of film discourse. Chapter 7], In Kinodialog. Obraz-smisl. Perevod [Film-dialogue. Imagesense. Translation]: kollektivnaja monografija / Pod obsch. red. prof. V.E. Gorshkovoj. Irkutsk, MGLU EALI, 247-278, available at: http://rucont.ru/efd/326468

Kolodina, E.A. (2013). Vzaimodeistvie semioticheskikh system v sozdanii smisla kinodialoga: avtoref. dis. ... kand. filol. nauk: 10.02.19 [Semiotic systems interaction in the formation of film dialogue sense: Abstract of the thesis for a Candidate of Philology degree: 10.02.19], Irkutsk, $22 \mathrm{p}$.

Nelyubin, L.L. (2003). Tolkovij perevodovedcheskij slovar' [Explanatory Dictionary of Translation Studies]. Moscow, Flinta: Nauka, 320 p.

SFS (2004). Sovremennij filosofskij slovar' [Modern Dictionary of Philosophy]. Moscow, Academicheskii proekt, $864 \mathrm{p}$.

Truby, J. (2010). Anatomie du scénario. Paris, Nouveau Monde Editions, 350 p. 


\section{Аудиовизуальный перевод}

\section{в свете основных законов диалектики}

\section{В.Е. Горшкова}

Евразийский лингвистический институт Россия, 664025, Иркутск, ул. Ленина, 8

В статье обоснована возможность использования диалектики как формы и способа теоретического осмысления фактов действительности в приложении к аудиовизуальному переводу. Действие основных законов диалектики, а именно законов единства и борьбы противоположностей, перехода количественных изменений в качественные и закона отрицания отрицания раскрываются на примерах эволюции аудиовизуальной терминологии, перевода сниженной лексики, передачи иностранного акцента персонажей фильма.

Ключевые слова: аудиовизуальный перевод, перевод субтитрами, дублирование, диалектика, единство и борьба противоположностей, переход количества в качество, закон отрицания отрицания.

Научная специальность: 10.02.20 - сравнительно-историческое, типологическое и сопоставительное языкознание. 